\title{
Spatial distribution of sea-level markers on Lesvos Island (NE Aegean Sea): Evidence of differential relative sea-level changes and the neotectonic implications
}

\author{
Matteo Vacchi ${ }^{\mathrm{a}, *}$, Alessio Rovere ${ }^{\mathrm{a}, \mathrm{e}}$, Nickolas Zouros ${ }^{\mathrm{b}}$, Stéphane Desruelles ${ }^{\mathrm{c}}$, Vincent Caron ${ }^{\mathrm{d}}$, Marco Firpo ${ }^{\mathrm{a}}$ \\ a Department for the Study of the Territory and its Resources, University of Genova, Genova, Italy \\ ${ }^{b}$ Department of Geography, University of Aegean, Mytilene, Lesvos Island, Greece \\ c UMR 8185 ENeC Paris-Sorbonne/CNRS et EA 4284 TRAMe Université de Picardie Jules Verne, Amiens, France \\ ' UMR-CNRS 8217, Géosystèmes, Laboratoire de Géologie, Université de Picardie Jules Verne, Amiens France \\ e Lamont-Doherty Earth Observatory, Palisades, NY, USA
}

\section{A R T I C L E I N F O}

\section{Article history}

Received 19 October 2011

Received in revised form 7 March 2012

Accepted 11 March 2012

Available online 17 March 2012

Keywords:

Coastal uplift

Relative sea-level changes

Tectonic geomorphology

Aegean Sea, Lesvos Island

\begin{abstract}
A B S T R A C T
The aim of this study is to provide new data on relative sea-level changes and neotectonics of the northeastern Aegean Sea region (Eastern Mediterranean) through the analysis of the coastal geomorphology of Lesvos, the third largest Greek island. There is a paucity of presently available data in this sector of the Aegean Sea, which is a tectonically active area strongly controlled by the North Anatolian Fault. In this paper, morphological, biological and sedimentary records of paleo-sea levels have been used to reconstruct relative sea-level changes, to identify variations in the tectonic regimes as well as to assess the paleoseismicity in the studied areas. According to the results, late Quaternary relative sea-level changes at Lesvos were not homogenous and variations in the tectonic setting played a crucial role in the coastal evolution. The NW-SE trending faults on the southern shore of the island control a significant uplift affecting about $30 \mathrm{~km}$ of coastline. This uplift trend is controlled by the footwall of the Lesvos Fault, a major offshore normal fault that has been subject to relatively little quantitative investigation. Radiocarbon dating indicated that the last co-seismic uplift took place at 3365-3963 cal yr BP and resulted in about $0.75 \mathrm{~m}$ of vertical displacement. In contrast, all the paleo-sea-level markers mapped in the northeastern sector were presently underwater and, despite the high seismicity of the area, no evidence of coastal uplift was observed in this part of the island. Thus, the paper provides the first field evidence of a differential late Quaternary evolution of Lesvos Island. In addition, results represent the first quantitative information on the activity of the Lesvos Fault, suggesting a reconsideration of its importance in the neotectonics of the area.
\end{abstract}

(c) 2012 Elsevier B.V. All rights reserved.

\section{Introduction}

Due to its geodynamic setting, many sectors of the Mediterranean basin exhibit evidence of differential relative sea-level (RSL) change during their late Quaternary evolution (Pirazzoli, 2005; Ferranti et al., 2006; Stewart and Morhange, 2009). The Aegean region (Greece, Eastern Mediterranean) is one of the most seismically active areas in the world and, as such, has been the focus of several papers dealing with coastal morphotectonics (Stiros et al., 2009; Cundy et al., 2010; Evelpidou et al., 2012) and relative sea-level (RSL) changes (Perissoratis and Cosnipoliatis, 2003; Poulos et al., 2009; Pavlopoulos et al., 2010).

In the Mediterranean, geomorphological investigations have proved particularly useful for extracting quantitative information, especially on coastal uplift (Pirazzoli, 2005; Ferranti et al., 2007, 2008; Filocamo et al., 2009) and paleoseismicity (Stiros et al., 2000;Mastronuzzi and Sansò, 2002; Palyvos et al., 2008; Stiros et al., 2009). In fact, the interaction between coastal processes (e.g. mechanical erosion) and uplifting fault

\footnotetext{
* Corresponding author.

E-mail address: matteo.vacchi@unige.it (M. Vacchi).
}

blocks contributes to the preservation of geomorphologic and/or biological records of vertical movements through time (Palyvos et al., 2008). As a result, detailed mapping of paleo-sea-level markers has been often used as a tool to quantify coastal uplift and RSL changes. Greece has always been a major focus of RSL studies: many authors reported on ancient RSL in the southern Aegean (Kontogianni et al., 2002; Pirazzoli, 2005; Gaki-Papanastassiou et al.; 2009; Stiros et al., 2009), in the eastern and western central sectors (Pirazzoli et al., 1999; Stiros et al., 2000; Desruelles et al., 2009; Nixon et al., 2009 Evelpidou et al., 2011; 2012) as well as in northwestern Aegean (Pavlopoulos et al., 2007; Ghilardi et al., 2008a,b; Cundy et al., 2010; Pavlopoulos et al., 2010). In contrast, few data are presently available on the northeastern sector of the Aegean Sea, which is a tectonically active area strongly controlled by the North Anatolian Fault (Koral et al., 2009; Erginal et al., 2010).

The aim of this study is to provide new data on RSL changes and the neotectonics of the northeastern Aegean through the analysis of the coastal geomorphology of Lesvos (Fig. 1a), the largest island in this sector. Although Lesvos has been a major attraction for many geoscientists in recent years (Pe-Piper and Piper, 1992; Fytikas et al., 1999; Novak and Soulakellis, 2000; Koufos et al., 2003; Kouly 


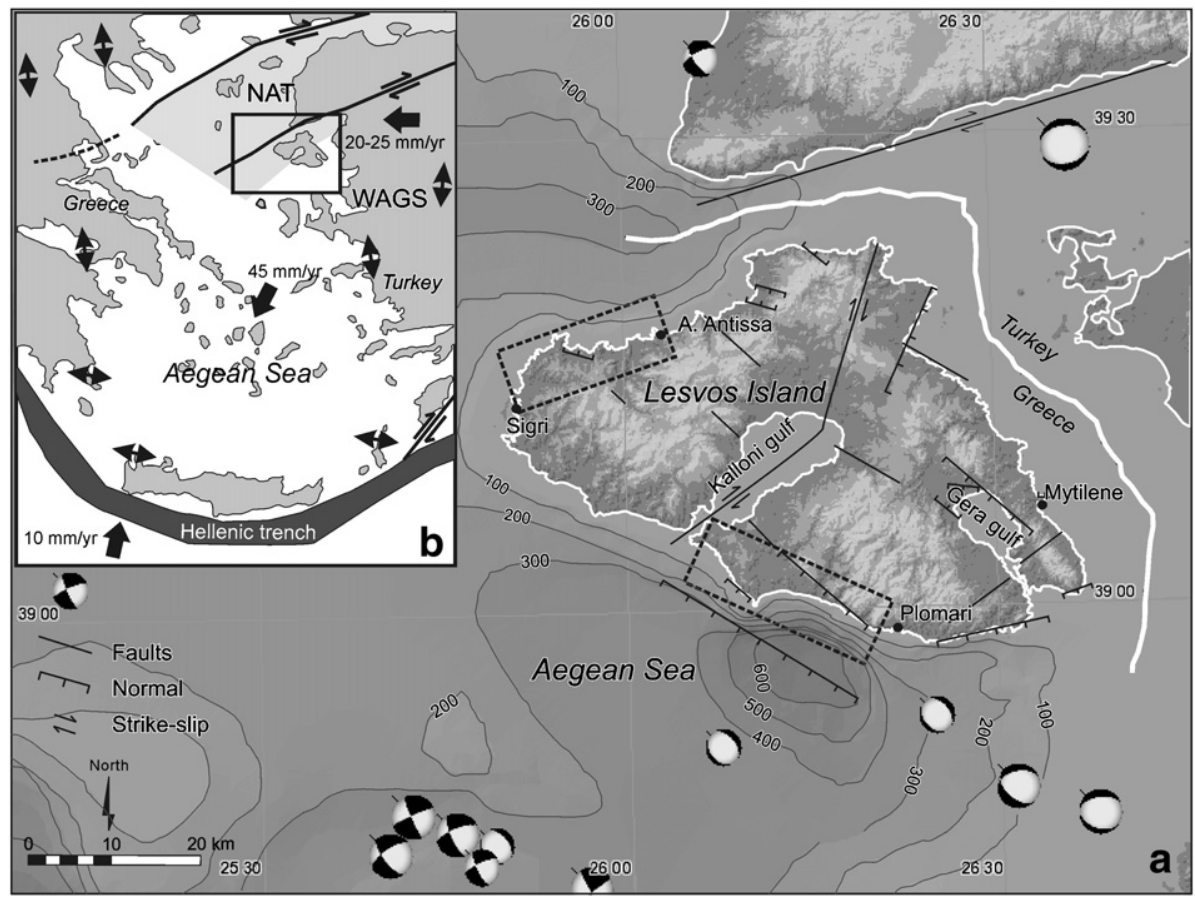

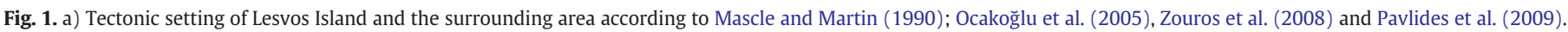

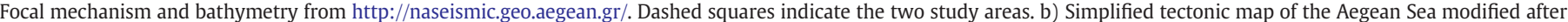
Papazachos et al., 1998. Black square indicates the geographical location of Lesvos Island. NAT is the North Anatolian Trough and WAGS is the West Anatolian Graben System.

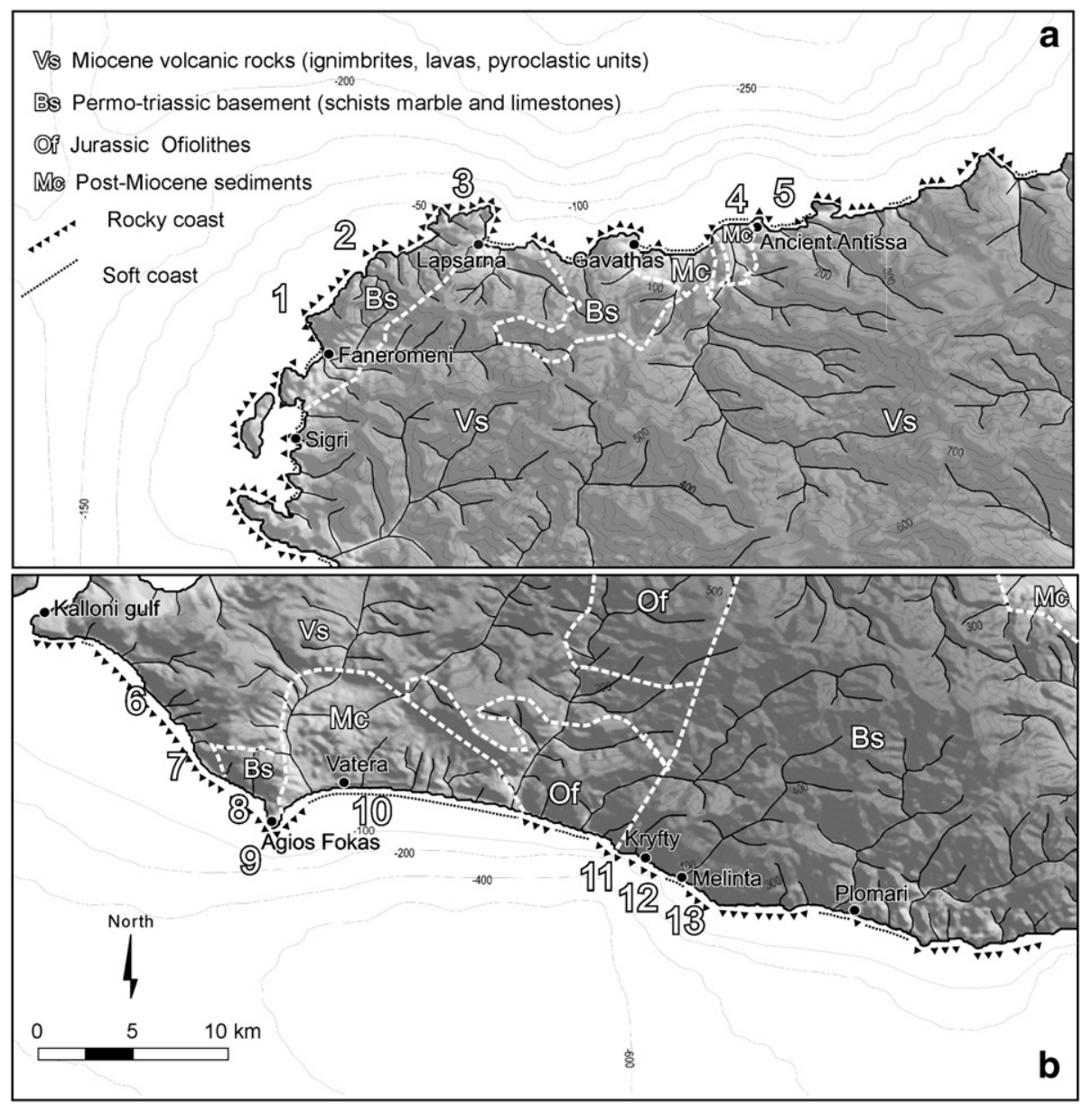

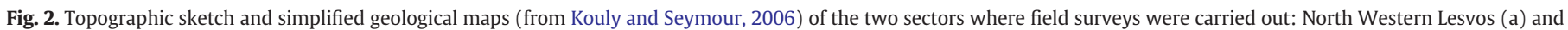
South Eastern Lesvos (b). Numbers indicate the location of the paleo-sea-level markers reported in this study (details in Table 1). 
and Seymour, 2006; Zouros, 2007; Rovere et al., 2011b) detailed studies of its coastal geomorphology are still lacking. In this paper, we present new data on the morphological, biological and sedimentary records of paleo-sea-levels in two sectors of Lesvos, and discuss their potential use to reconstruct RSL changes in order to identify variations in tectonic regimes and to assess the paleoseismicity.

\section{Material and methods}

\subsection{Study area}

Lesvos, the third largest Greek island, is located in the northeastern Aegean Sea (Fig. 1b). Its morphology is shaped by the presence of two large gulfs of structural origin (Fig. 1a, Zouros et al., 2008). The largest one (Gulf of Kalloni) divides the island into two main sectors. The geology of Lesvos is dominated by Miocene volcanic rocks covering the alpine basement, which is formed by a Jurassic ophiolitic sequence overthrusted on the Paleozoic crystalline limestones and schists. Three main geological units comprise the geological structure of the island: i) an autochthonous series of pre-alpine and alpine formations (schists with intercalations of crystalline limestones and dolomites), ii) an allochthonous series of alpine volcano-sedimentary formations and ophiolitic rocks), and iii) post-alpine formations (mainly andesitic lavas and pyroclastic formations as well as alluvial and lacustrine sediments) (Fig. 2a,b; Novak and Soulakellis; 2000; Mountrakis et al. 2001; Kouly and Seymour, 2006).

The northeastern Aegean region is a geotectonically complex area. Its geodynamic status (Fig. 1b) is directly affected both by the westward continuation in the Aegean Sea of the North Anatolian Fault (NAT, North Aegean Trough) and the West Anatolia Graben System (WAGS, in Asia Minor) which produced a significant historical seismicity (Papazachos and Kiratzi, 1996; Papazachos and Papazachou, 1997; Kiratzi and Louvari, 2003). As a result of the interaction between those tectonic systems, there is a strong diversity in fault trending and character of the broad Lesvos area which is presently characterized by the activity of both normal and strike slip faults (Fig. 1a, Roumelioti et al., 2011).

From a geomorphologic point of view, the Lesvos coastlines are mainly characterized by steep cliffs alternating with gravel beaches. Soft coasts are relatively less developed, occurring typically adjacent to small coastal plains, especially inside the two gulfs (Novak and Soulakellis, 2000). Spring tides are low, not exceeding $0.25 \mathrm{~m}$ on the eastern coast (Vousdoukas et al., 2009a,b) and $0.2 \mathrm{~m}$ on the western one (Velegrakis et al., 2008).

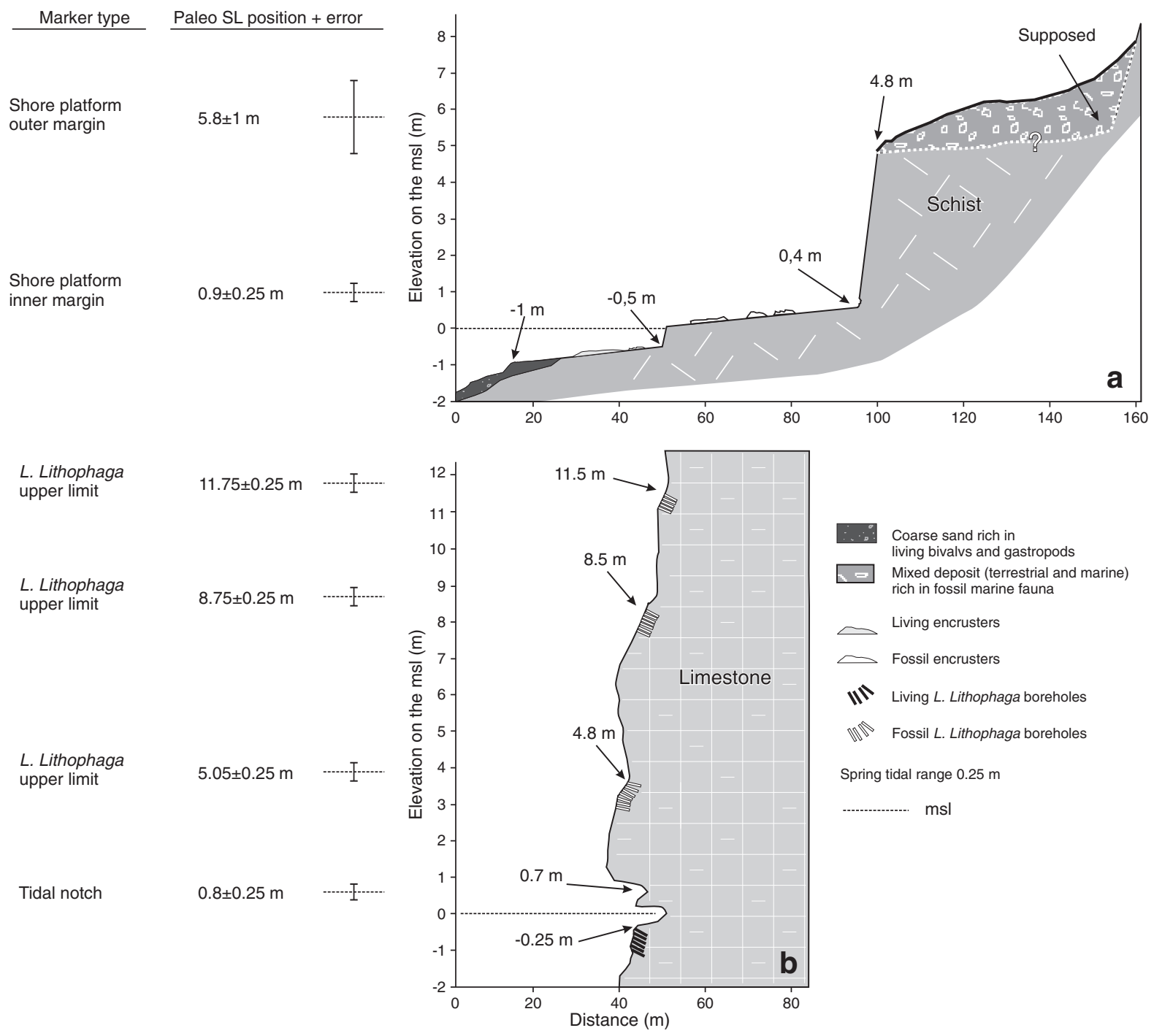

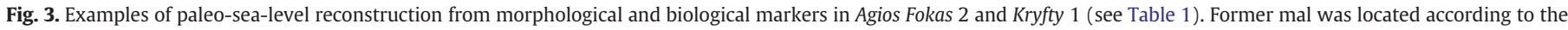

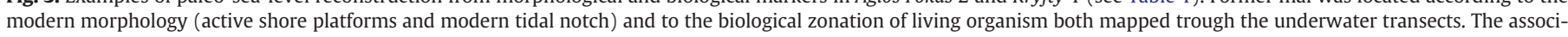
ated vertical error is given by the local spring tidal range. 


\subsection{Sea level markers}

A detailed mapping of paleo-sea-level markers was carried out between September 2009 and December 2011. Field mapping was focused on two areas covering about $60 \mathrm{~km}$ of coastline (Fig. 1b). The first is located in northwestern Lesvos, between the village of Sigri and the archeological site of Ancient Antissa (Fig. 2a). The second is located in the southeastern part of the island, between the gulf of Kalloni and the village of Plomari (Fig. 2b).

The elevation of each marker was measured using a $3 \mathrm{~m}$ metal bar with centimeter division and built-in spirit level, a weight-suspended measuring tape and a laser level. Site location was determined using handheld GPS with an average horizontal error of $5 \mathrm{~m}$.

Elevation was referenced to the biological zero (i.e. the point where the first stands of the Cystoseira spp. and Lithophyllum spp. occurred), which has often been used to determine mean sea level with reasonable accuracy $( \pm 0.1 \mathrm{~m})$ in microtidal environments (Laborel and Laborel-Deguen, 1996; Stiros et al., 2000; Schembri et al., 2005). Underwater SCUBA transects were carried out down to $20 \mathrm{~m}$ to identify the occurrence of submerged sea-level markers following the methodologies proposed by Collina-Girard (2002) and Rovere et al. (2011a). Depth was measured using a 3 m metal bar (in shallow water) and averaging 2 accurate electronic depth gauges with a final precision of $0.5 \mathrm{~m}$ (at depths $\geq-3 \mathrm{~m}$, Rovere et al., 2010). Readings were noted using a PVC slate. Each morphological and biological record of past sea level requires the identification of its relationship to mean sea-level (msl) at the time of its formation (Palyvos et al., 2008). This is mainly related to the local coastal dynamics and lithology, and comparison with the modern seafloor features is fundamental to understand this relationship in each study area. For this reason underwater surveys were also carried out to measure the bathymetrical extent of the active shore platform, the morphology and amplitude of the modern tidal notch as well as biological zonation of the living species found within the fossil units (Laborel and Laborel-Deguen, 1996, Schembri et al., 2005; Rovere et al., 2011a; Scicchitano et al., 2011). Such data, collected at each site where a paleo-sea-level marker occurs, were essential for the interpretation of the meaning of each indicator (see below; Fig. 3).

The following markers were used to reconstruct the paleo-sealevel position. Unless differently specified, the associated vertical error is represented by the local tidal range (i.e. $\pm 0.25 \mathrm{~m}$ on the eastern coast and $\pm 0.20 \mathrm{~m}$ on the west).

i) Tidal notches are considered very accurate paleo-sea-level indicators, particularly in microtidal environments (Ferranti et al., 2006; Antonioli et al., 2007; Pirazzoli, 2007; Stewart and Morhange, 2009). Observations of the modern morphology identified a frequent $\mathrm{V}$-shaped or U-shaped notch profile along the limestone rocky coast. Because wave exposure is generally low, notch amplitude did not exceed $0.5 \mathrm{~m}$. As reported by Rust and Kershaw (2000), Antonioli et al. (2006) and Pirazzoli (2007), the observed notch morphology has its vertex located near msl.
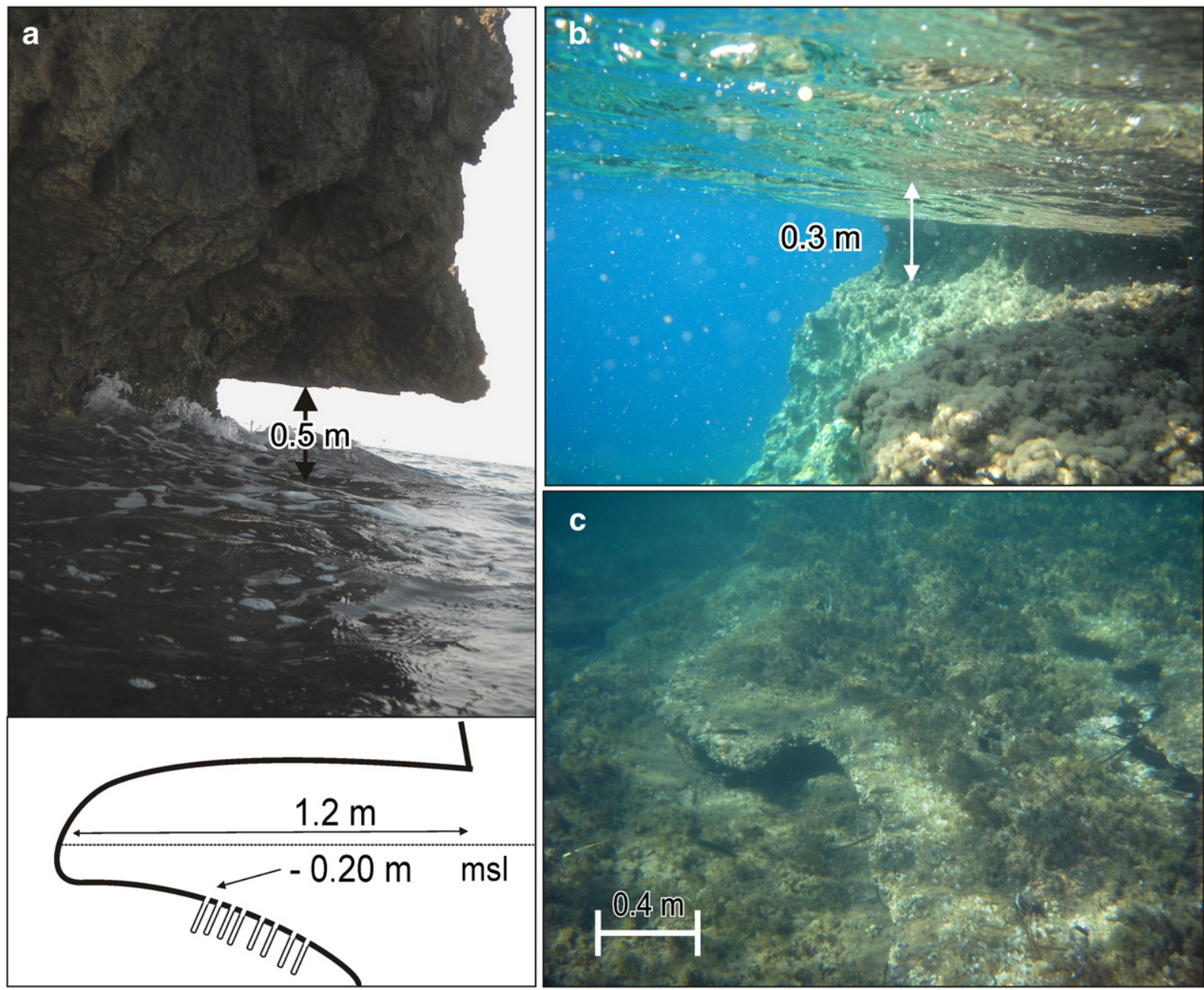

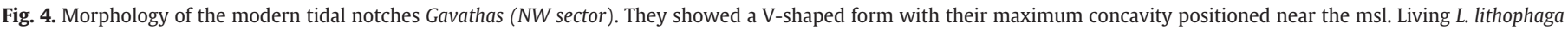

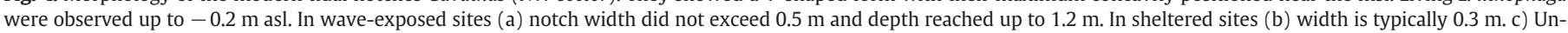
derwater beachrock mapped in the Ancient Antissa (NW sector) developing from -1.2 down to $-1.8 \mathrm{~m}$ asl. 
For these reasons, we derived the paleo-msl measuring the elevation at the notch vertex (i.e. the maximum concavity) (Fig. 3b, Laborel and Laborel-Deguen, 1996; Kershaw and Guo, 2001; Palyvos et al., 2008; Pirazzoli, 2007).

ii) Shore platforms and benches, when their inner margin is clearly identifiable, provide minimum constraints to past sea levels as, in microtidal environments, they are formed slightly below it (Scicchitano et al., 2011). On the basis of their modern morphology observed underwater, shore platforms were considered to indicate a sea level positioned $0.5 \mathrm{~m}$ above the inner margin (Fig. 3a). Where the inner margin was unidentifiable, the former sea level was located $1 \mathrm{~m}$ above the outer margin. This is based on the modern platform morphology as well as on the geometrical features of the uplifted shore platforms in which both margins were observable (Fig. 3a). However, use of this marker (often covered by beach deposits) implies a lower level of accuracy $( \pm 1 \mathrm{~m})$ in indicating the paleo-sea level.

iii) In the Mediterranean, the horizontal upper limit of Lithophaga lithophaga borehole bands represent a precise indicator of former msl (Laborel and Laborel-Deguen, 1996; Stiros et al., 2000; Lambeck et al., 2004; Pirazzoli et al., 2004). L. lithophaga typically lives in the infralittoral zone, extending from the msl down to about $-30 \mathrm{~m}$. The upper limit of the living range of these organisms depends on the local properties of the cliff and physical parameters (i.e. wave exposure) (Riedl, 1964). Underwater observations were used to measure in situ the vertical distance between the upper limit of living $L$. lithophaga and msl. This value was then used to place the paleo-sea level above fossil L. lithophaga borehole bands (Fig. $3 b$ ).

iv) Beachrocks occur in different sites along the coastline. In the literature, issues such as beachrock cementation environment and their use as sea-level markers are widely debated (Vött et al., 2010). An intertidal formation (due to the mixing between carbonate-saturated marine water and fresh groundwater) is proposed by Neumeier (1998, 1999), Desruelles et al. (2004), Turner (2005) and Vousdoukas et al. (2007) Desruelles et al. (2009). Conversely, Kellettat (2006) suggested a supratidal formation in the spray zone. Issues about the use of beachrocks as precise sea-level indicators were also raised by Knight (2007) and Vött et al. (2010). However, several studies carried out in the Aegean Sea pointed out the importance of beachrocks as sea level indicator (Desruelles et al., 2004; Fouache et al., 2005; Pavlopoulos et al., 2007; Desruelles et al., 2009; Evelpidou et al., 2011) especially if coupled with other morphological and biological proxies (Neumeier et al., 2000; Nixon et al., 2009). For this reason, we followed the robust methodology proposed by Desruelles et al. (2009) to analyze this marker: 10 beachrocks were sampled in their front (seaward) and end (landward) slabs, and thin sections were cut in order to perform petrographic (polarizing and scanning electron microscope) and microstratigraphic analyses. These observations allowed the characterization of the constituents, the presence of bioclasts as well as the type of the cements. The former shoreline position was reconstructed, averaging the elevation of front and end beachrock margins. This measure represents the central axis of the former intertidal zone. In the presence of particular sedimentary structures (such as keystone vugs) the vertical error is represented by the local tidal range. Because microscope observations did not identify these structures in our samples, the associated vertical error increased to $\pm 0.5 \mathrm{~m}$ on the eastern sector and $\pm 0.4 \mathrm{~m}$ on the west, following the methodology proposed by Desruelles et al. (2009).

Table 1

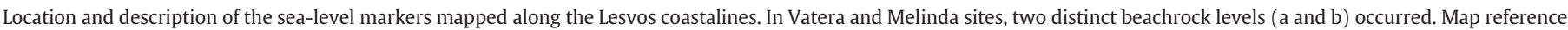
is shown in Figs. 2 and 9. See Section 2.2 for the detail of the paleo-sea-level reconstruction and the given error.

\begin{tabular}{|c|c|c|c|c|c|}
\hline Map ref. & Coordinates & Sector & Marker & Elevation on msl (m) & Paleo-sea level position and relative error ( $\mathrm{m}$ ) \\
\hline 1 & $39^{\circ} 15^{\prime} 09.6^{\prime \prime}-25^{\circ} 51^{\prime} 32.2^{\prime \prime}$ & NW & Beachrock (end; front) & $-0.9 ;-1.6$ & $-1.25 \pm 0.4$ \\
\hline 2 & $39^{\circ} 16^{\prime} 08.3^{\prime \prime}-25^{\circ} 52^{\prime} 34.3^{\prime \prime}$ & NW & Beachrock (end; front) & $-1.1 ;-1.5$ & $-1.3 \pm 0.4$ \\
\hline 3 & $39^{\circ} 17^{\prime} 17.9^{\prime \prime}-25^{\circ} 54^{\prime} 16.5^{\prime \prime}$ & NW & Beachrock (end; front) & $-1 ;-1.6$ & $-1.3 \pm 0.4$ \\
\hline 4 & $39^{\circ} 17^{\prime} 19.0^{\prime \prime}-26^{\circ} 01^{\prime} 14.6^{\prime \prime}$ & NW & Beachrock (end; front) & $-1.2 ;-1.8$ & $-1.5 \pm 0.4$ \\
\hline 5 & $39^{\circ} 17^{\prime} 16.0^{\prime \prime}-26^{\circ} 01^{\prime} 21.0^{\prime \prime}$ & NW & Beachrock (end; front) & $-1.1 ;-1.8$ & $-1.45 \pm 0.4$ \\
\hline 6 & $39^{\circ} 02^{\prime} 32.93^{\prime \prime}-26^{\circ} 08^{\prime} 02.7^{\prime \prime}$ & SE & Shore platform inner margin & 0.4 & $0.9 \pm 0.25$ \\
\hline \multirow[t]{2}{*}{7} & $39^{\circ} 01^{\prime} 41.7^{\prime \prime}-26^{\circ} 08^{\prime} 36.9^{\prime \prime}$ & SE & Shore platform inner margin & 0.4 & $0.9 \pm 0.25$ \\
\hline & & & Shore platform outer margin & 4.8 & $5.8 \pm 1$ \\
\hline \multirow[t]{5}{*}{8} & $39^{\circ} 00^{\prime} 18.9^{\prime \prime}-26^{\circ} 10^{\prime} 07.4^{\prime \prime}$ & SE & Shore platform inner margin & 0.5 & $1 \pm 0.25$ \\
\hline & & & Shore platform outer margin & 4.1 & $5.1 \pm 1$ \\
\hline & & & Shore platform outer margin & 10.8 & $11.8 \pm 0.25$ \\
\hline & & & Tidal notch & 0.8 & $0.8 \pm 0.25$ \\
\hline & & & Beachrock (end; front) & $1.1 ;-0.2$ & $0.45 \pm 0.4$ \\
\hline \multirow[t]{3}{*}{9} & $39^{\circ} 00^{\prime} 53.7^{\prime \prime}-26^{\circ} 09^{\prime} 51.1^{\prime \prime}$ & SE & Shore platform inner margin & 0.5 & $1 \pm 0.25$ \\
\hline & & & Shore platform outer margin & 10.9 & $11.9 \pm 1$ \\
\hline & & & Tidal notch & 0.7 & $0.7 \pm 0.25$ \\
\hline \multirow[t]{2}{*}{10} & $39^{\circ} 01^{\prime} 07.3^{\prime \prime}-26^{\circ} 11^{\prime} 42.6^{\prime \prime}$ & SE & Beachrock a (end; front) & $0.1 ;-1.2$ & $0.65 \pm 0.4$ \\
\hline & & & Beachrock b (end; front) & $-2.1 ;-2.4$ & $-2.25 \pm 0.4$ \\
\hline \multirow[t]{5}{*}{11} & $38^{\circ} 59^{\prime} 44.9^{\prime \prime}-26^{\circ} 17^{\prime} 31.1^{\prime \prime}$ & SE & Tidal notch & 0.8 & $0.8 \pm 0.25$ \\
\hline & & & Lithophaga band & 4.8 & $5.05 \pm 0.25$ \\
\hline & & & Lithophaga band & 8.5 & $8.75 \pm 0.25$ \\
\hline & & & Lithophaga band & 11.5 & $11.75 \pm 0.25$ \\
\hline & & & Tidal notch & 0.7 & $0.7 \pm 0.25$ \\
\hline \multirow[t]{3}{*}{12} & $38^{\circ} 59^{\prime} 40.0^{\prime \prime}-26^{\circ} 17^{\prime} 46.0^{\prime \prime}$ & SE & Bench inner margin & 0.4 & $0.9 \pm 0.25$ \\
\hline & & & Lithophaga band & 4.6 & $4.85 \pm 0.25$ \\
\hline & & & Lithophaga band & 8.6 & $8.85 \pm 0.25$ \\
\hline \multirow[t]{4}{*}{13} & $38^{\circ} 59^{\prime} 14.7^{\prime \prime}-26^{\circ} 18^{\prime} 41.5^{\prime \prime}$ & SE & Beachrock a (end; front) & $0.5 ;-1.4$ & $-0.4 \pm 0.5$ \\
\hline & & & Beachrock b (end; front) & $-1.6 ;-3.1$ & $-2.35 \pm 0.5$ \\
\hline & & & Lithophaga band & 11.4 & $11.65 \pm 0.25$ \\
\hline & & & Shore platform inner margin & 11.2 & $11.7 \pm 0.25$ \\
\hline
\end{tabular}



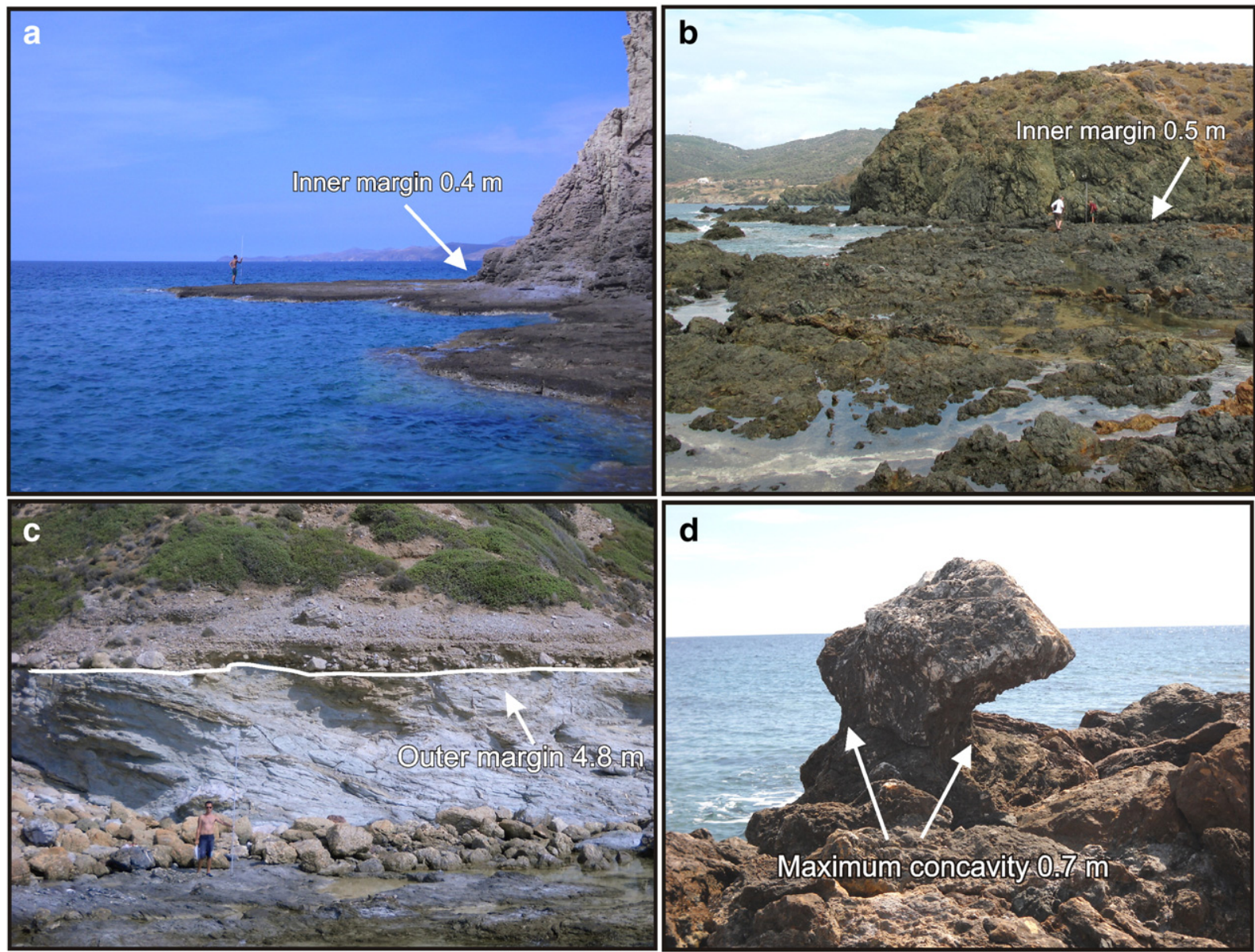

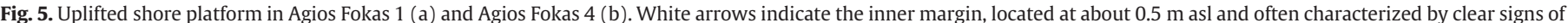

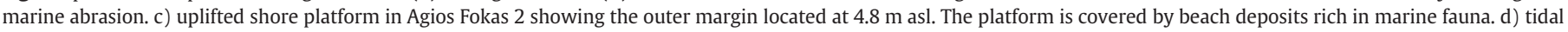
notch carved on isolated limestone blocks scattered on the uplifted platform in Agios Fokas 4

\subsection{Paleo-shoreline elevation and dating}

Altimetric correlation of the different markers was performed in order to estimate the paleo-shorelines elevation. Due to their high level of accuracy, tidal notches were used as primary sea-level indicators (Ferranti et al., 2006; Antonioli et al., 2007; Pirazzoli, 2007). The upper limit of $L$. Lithophaga bands and internal margin of shore platforms (or benches) were also particularly important markers (Stiros et al., 2000; Palyvos et al., 2008; Scicchitano et al., 2011).

The issues described above (see Section 2.2) concerning the use of beachrocks as precise sea-level indicators and the lower accuracy of the shore platform outer margins were taken into account in reconstructing the elevation of the paleo-shorelines. In fact, these markers were employed as secondary data, but they were especially useful in those coastal sectors where other indicators were lacking.

We dated the raised paleo-shorelines using fossil shells that were sampled on the uplifted shore platforms (see Results).
AMS ${ }^{14} \mathrm{C}$ technique was used for dating. Preliminary screening under scanning electron microscope was performed in order to eliminate samples showing evidence of recrystallisation. Radiocarbon age calibration was performed using the MARINE09 database of the software CALIB 6.0 (Stuiver and Reimer, 1993). A $\Delta \mathrm{R}$ value of $151 \pm 40$ years was used, corresponding to the local reservoir age correction for the North Eastern Aegean Sea (Siani et al., 2000; Reimer et al., 2009).

\section{Results}

\subsection{Altimetric distribution of sea level markers}

\subsubsection{Northwest Lesvos}

The northwestern part of Lesvos is characterized by steep cliffs carved in schists, lavas and volcano-sedimentary sequences (Fig. 2a). Limestone outcrops are only present near the village of Gavathas,

Table 2

AMS ${ }^{14} \mathrm{C}$ dating of fossil marine shells carried out in this study. Sampling elevation is expressed above mean sea level (asl). Calibration details are given in Section 2.3.

\begin{tabular}{|c|c|c|c|c|c|c|}
\hline Area & Map Ref & Lab. code & Specimen & Elevation (m) & Conventional age & 2 sigma calibration \\
\hline Agios Fokas 4 & 9 & Beta288251 & Serpulidae spp. & 0.5 & $3860 \pm 50$ & 3460-3812 ВР \\
\hline Agios Fokas 3 & 8 & Beta288252 & Patellidae spp. & 4.8 & $27,700 \pm 120$ & Not applicable \\
\hline Panagia Krifty 2 & 12 & Beta288253 & Serpulidae spp. & 0.6 & $4000 \pm 40$ & 3642-3963 ВР \\
\hline Panagia Krifti 2 & 12 & Beta288254 & Balanidae spp. & 0.6 & $3760 \pm 40$ & 3365-3648 BР \\
\hline Agios Fokas 3 & 10 & Beta288255 & Patellidae spp. & 11.0 & $29,160 \pm 150$ & Not applicable \\
\hline Agios Fokas 3 & 9 & Poz-36355 & Trochidae spp. & 0.4 & $3970 \pm 40$ & 3609-3924 BP \\
\hline
\end{tabular}


associated with modern tidal notches. Notch morphology is characterized by a V-shaped form with an average width of $0.5 \mathrm{~m}$ in waveexposed sites (Fig. 3a) decreasing to $0.3 \mathrm{~m}$ in sheltered areas (Fig. 3b). They reached up to $1.2 \mathrm{~m}$ in depth (Fig. 4a). Living L. lithophaga were observed during the underwater surveys occurring until $-0.20 \mathrm{~m}$ above msl (asl, Fig. 3a). No morphological or biological markers of raised shorelines were mapped along this sector. On the contrary, underwater beachrocks occurred in different sites characterized by lithological environments varying from schists (northern Sigri) to volcanic sequences (Ancient Antissa area, Fig. 4c). Underwater mapping identified the constant bathymetrical extent of the outcrops. The landward limit was between -0.9 and $-1.2 \mathrm{~m}$, whereas the seaward limit ranged between -1.5 and $-1.8 \mathrm{~m}$ asl (Table 1 ). Scattered broken beachrock slabs (not in place) were observed down to $-4 \mathrm{~m}$ asl.

\subsubsection{Southeastern Lesvos}

This sector is mainly characterized by steep rocky shorelines interrupted by the $\sim 7 \mathrm{~km}$-long beach of Vatera (Fig. 2b). The most evident morphological marker was an uplifted shore platform developing $6 \mathrm{~km}$ westwards of Agios Fokas cape (Table 1, Fig. 5a,b). The platform is continuous despite several changes of lithology occurring in the area. Its inner margin is often characterized by an abrasion notch and is positioned at about $0.5 \mathrm{~m}$ asl (Table 1, Figs. 3a, 5b). Isolated limestone blocks on the platform were characterized by tidal notches with maximum concavity ranging from 0.8 to $0.7 \mathrm{~m}$ asl (Table 1 , Fig. 5d).
Along the platform, marine shells were found both in cemented beach deposits and preserved in living position (encrusters) at about $0.5 \mathrm{~m}$ asl. The majority of the species observed are characteristic of the infralittoral zone (always submerged). AMS ${ }^{14} \mathrm{C}$ radiocarbon dating was performed on two fossil shells (Serpulidae spp. in living position and Trochidae spp. in a cemented beach deposit) located $4 \mathrm{~km}$ from each other. They yielded calibrated ages of 3460-3812 cal yr BP and 3609-3924 cal yr BP (Table 2). Higher levels of uplifted shore platforms (Table 1) were mapped along this sector at elevations of approximately 4.5 and $11 \mathrm{~m}$ asl. These levels are recurrent in 2 sites along the coastline and are always covered by beach deposits rich in marine fauna (Fig. 5c). Due to the thick beach deposits lying on the platforms, identification of their inner margin was difficult (Fig. 3a). However, the outer margin was easily identified and mapped. Marine shell remains (Patellidae spp.) were sampled in two different beach deposits located respectively at 4.8 and $11.2 \mathrm{~m}$. AMS ${ }^{14} \mathrm{C}$ radiocarbon dating indicated a pre-Holocene age for both shells (Table 2).

Due to the favorable lithological setting (limestones), several sealevel markers were observed east of Agios Fokas cape, in particular along the coastal tract comprised between the Panagia Krifti cove and the village of Melinda (Table 1). The first is a sheltered cove carved in Triassic limestones where a continuous uplifted tidal notch (maximum concavity $0.8 \mathrm{~m}$ asl) is present. In the whole sector, underwater transect observations identified the large presence of living L. lithophaga occurring to $-0.25 \mathrm{~m}$ asl. Three well-preserved fossil bands of $L$. lithophaga boreholes were mapped on the western side of the cove (Fig. 4). The upper limit of each band was located respectively at 4.8, 8.5 and
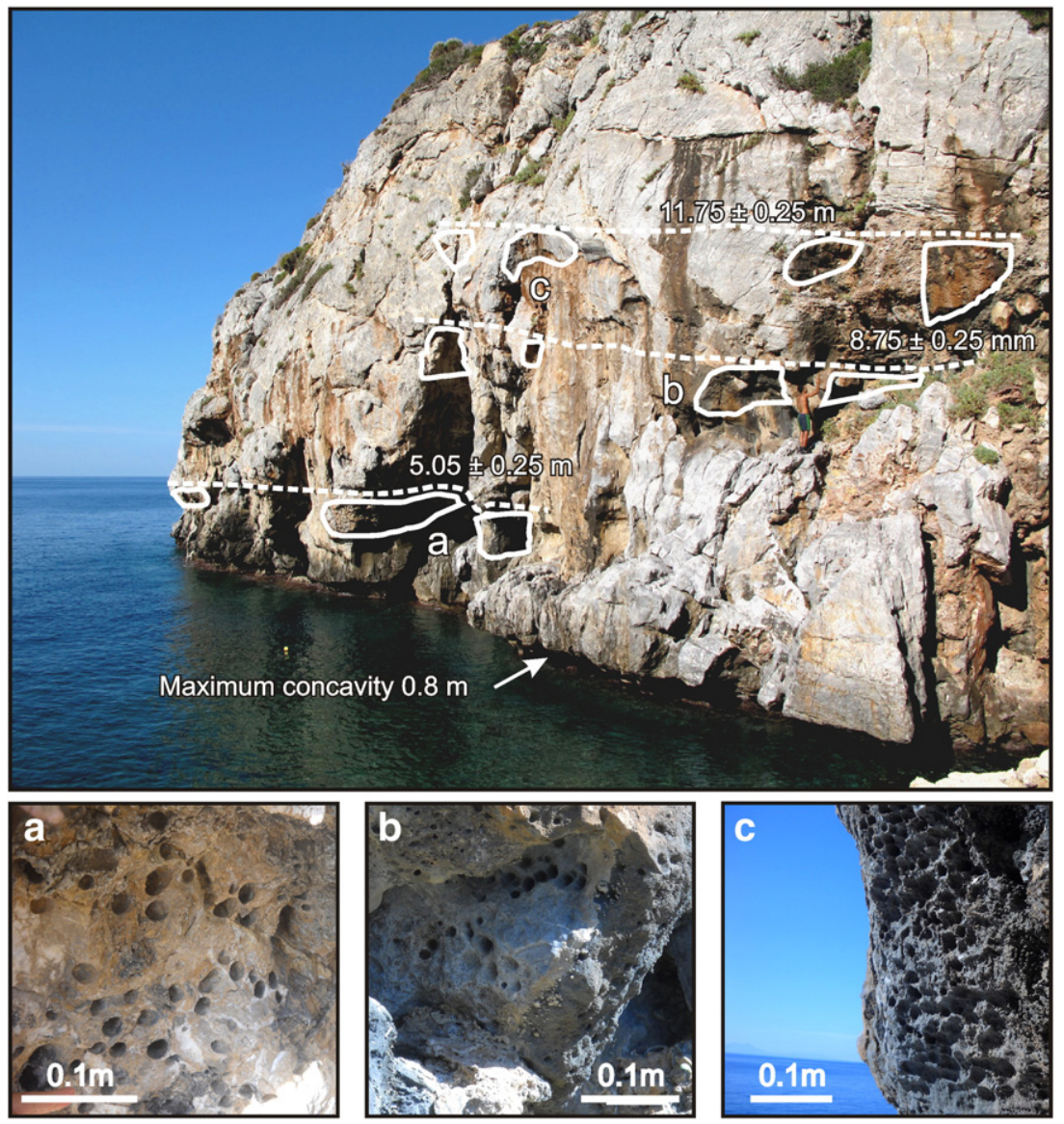

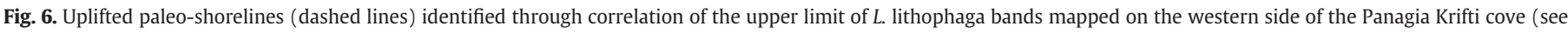

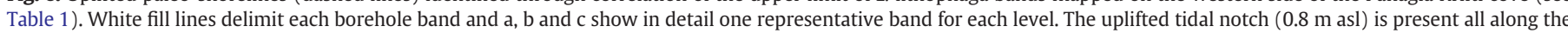
cove. Scale of the photo is given by the person near band $b$. 
$11.5 \mathrm{~m}$ asl (Fig. 3b). Relicts of narrow uplifted benches occurred east of Panagia Krifti as far as the village of Melinda (Table 1). They were covered by cemented beach deposits and remains of marine fossils in living position. Two samples of marine shells (Serpulidae spp. and Balanidae spp.) in living position were sampled; AMS ${ }^{14} \mathrm{C}$ dating yielded calibrated ages of 3642-3963 cal yr BP and 3365-3648 cal yr BP (Table 2). Uplifted tidal notches, having a maximum concavity of $0.7 \mathrm{~m}$ asl, were also observed in this site (Fig. 5a).

The L. lithophaga bands observed in Panagia Krifti cove were found at a constant elevation as far as the village of Melinda, except where lithological conditions did not favor their formation and preservation (i.e. in schists).

An uplifted shore platform was observed on top of a large limestone block in front of the village of Melinda (Table 1). A wellpreserved L. lithophaga borehole band (upper limit at $11.5 \mathrm{~m}$ ) characterized its inner margin (Fig. 7b).

Beachrocks occurred at two distinct levels both in Melinda and in Vatera (Table 1). A 1 m-thick beachrock was observed lying on the platform proximal to Agios Fokas cape (Table 1).

\subsection{Microstratigraphy of the beachrock cements}

The bounding materials observed between grains are early intertidal cements, peloidal cement, micritic filling (including internal sediments) and meteoric calcite cement (Fig. 6) (Neumeier, 1998; Vousdoukas et al., 2007; Desruelles et al., 2009). The latter is present in the Agios Fokas and the Melinda samples (Fig. 8, samples 9 and 14a) and in both cases follows a first fringe of early intertidal cement.

The observed early intertidal cements were characterized by micritic texture (often irregularly shaped and, probably, of microbial origin) or by limpid crystal fringes (palissadic or blocky texture). All these cements are typical of the marine phreatic zone (Vousdoukas et al., 2007; Desruelles et al., 2009). On the contrary, sparitic cements in stalactitic disposition or meniscus cements are characteristic of the marine vadose zone (Longman, 1980, Neumeier, 1998). Peloidal cement is a micrite partially replaced by coalescent pellet clusters. These pellets are agglomerates of particles that could form during the diagenesis inside the pore space within the intertidal zone. They are probably associated to a precipitate of high magnesium calcite caused by bacterial action (Vousdoukas et al., 2007). The observed micritic fillings were often geotropic deposits resulting from gravity in the beachrock pore space. These micritic grains were often observed at the bottom of pore spaces in geopetal position (Desruelles et al., 2009). They may come from the percolation of fine particles originating from the water/sediment interface, in the intertidal, lower supratidal and upper subtidal zone. They could be contemporary or posterior to the beachrock formation (Neumeier, 1998, 1999).

Microscope analysis identified that cements are always less than $50 \mu \mathrm{m}$ thick. As a result, their extraction for radiocarbon dating was extremely difficult. Moreover, the presence of micritic fillings, often recrystallized, could affect the radiocarbon dating producing apparently older dates (Desruelles et al., 2009). For these reasons, beachrock analysis did not provide chronological constraints, despite the literature available for the Aegean Sea (e.g. Pavlopoulos et al., 2007; Vousdoukas et al., 2007; Desruelles et al., 2009) indicating that beachrocks most likely formed during Late Holocene sea-level stands between 5000 and 500 cal yr BP. In particular, Desruelles et al. (2009) derived 3 paleo-sea-level stands from beachrocks dating in a sector considered tectonically stable since the Pliocene (Mykonos, Delos and Rhenia islands, central Aegean Sea): these stands are located, respectively, at $-3.6 \pm 0.5 \mathrm{~m}(\sim 2000 \mathrm{BC})$, at $-2.5 \pm$ $0.5 \mathrm{~m}(\sim 400 \mathrm{BC})$ and at $-1 \pm 0.5 \mathrm{~m}(1000 \mathrm{AD})$.

Additional data could be gathered from the beachrock microstratigraphy. Two samples from the southeastern sector (Fokas W and Melinda, Fig. 8, samples 9 and 14a) recorded in their cement stratigraphy the progressive uplift of the beachrocks. In both cases, a displacement from a former intertidal position to a supratidal one was observed in the samples, clearly indicated by evidence of bioclasts dissolution (Fig. 6, sample 9) and presence of meteoric cements (Fig. 6, sample 9 and 14a). Such a trend was not observed in the beachrocks sampled in the northwest sector of the island (Fig. 8, samples 1 and 5).

\subsection{Identification of recurring paleo-shorelines}

The integrated analysis of the different markers allowed the identification of recurring altimetric intervals in the different sectors of Lesvos Island (Fig. 9a).

Along the northwestern sector of the island, the paleo-sea-level markers are presently below msl. In this part of the island, sea-level indicators are represented only by beachrocks. They always occur underwater, indicating a former intertidal zone located at $-1.3 \pm 0.4 \mathrm{~m}$.

On the contrary, several raised sea-level markers were mapped in the southeastern sector of the island. Their correlation allowed the reconstruction of four recurring paleo-shorelines. They are located respectively at $0.75 \pm 0.25,4.8 \pm 0.25,8.8 \pm 0.25$ and $11.75 \pm 0.25 \mathrm{~m}$ asl. Correlation of the underwater beachrocks in this area showed two levels at $-0.5 \pm 0.5$ and $-2.3 \pm 0.5 \mathrm{~m}$.
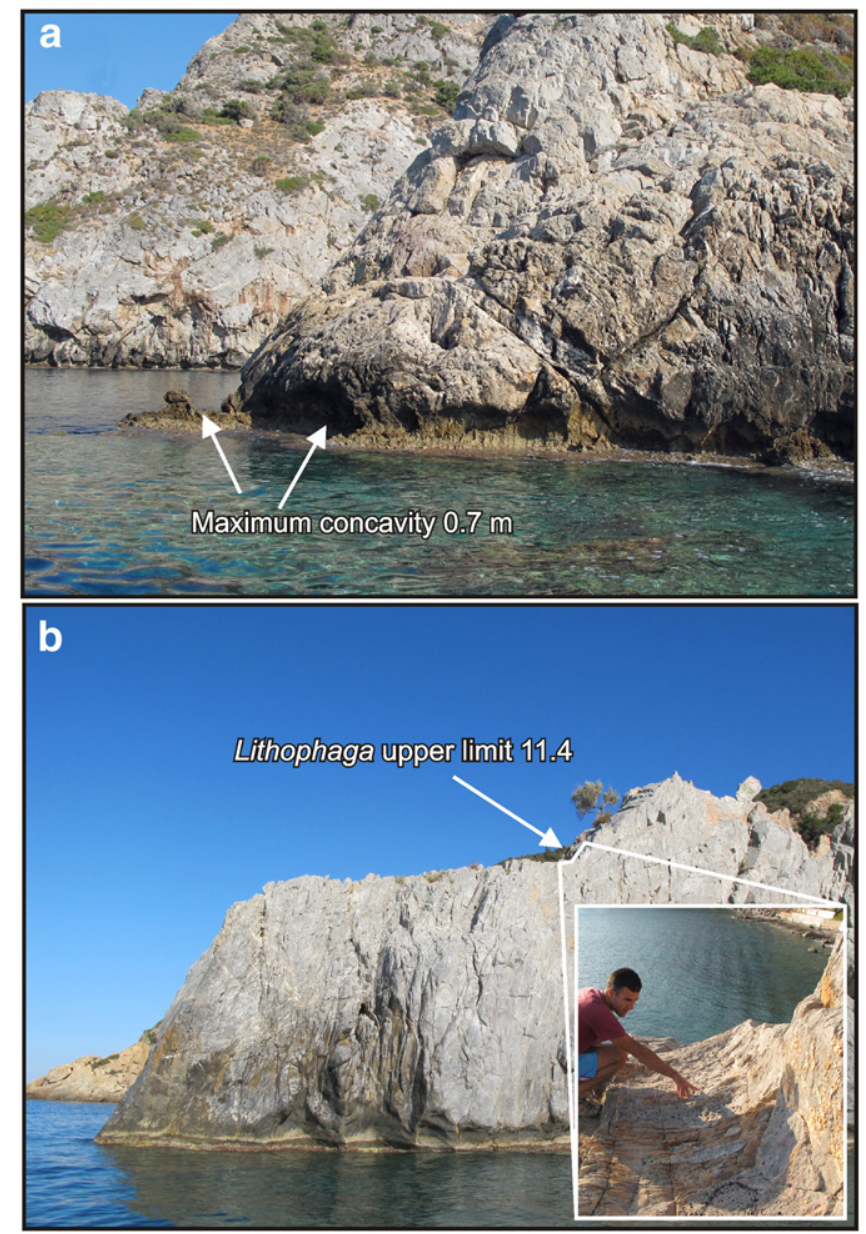

Fig. 7. a) uplifted tidal notch in the sector comprised between Panagia Krifti and Melinda. The notch is no longer active being completely above the mesolittoral zone. b) uplifted shore platform occurring in Melinda. Inner margin showed a well preserved band of $L$. lithophaga with the upper limit positioned at $11.5 \mathrm{~m}$ asl. 


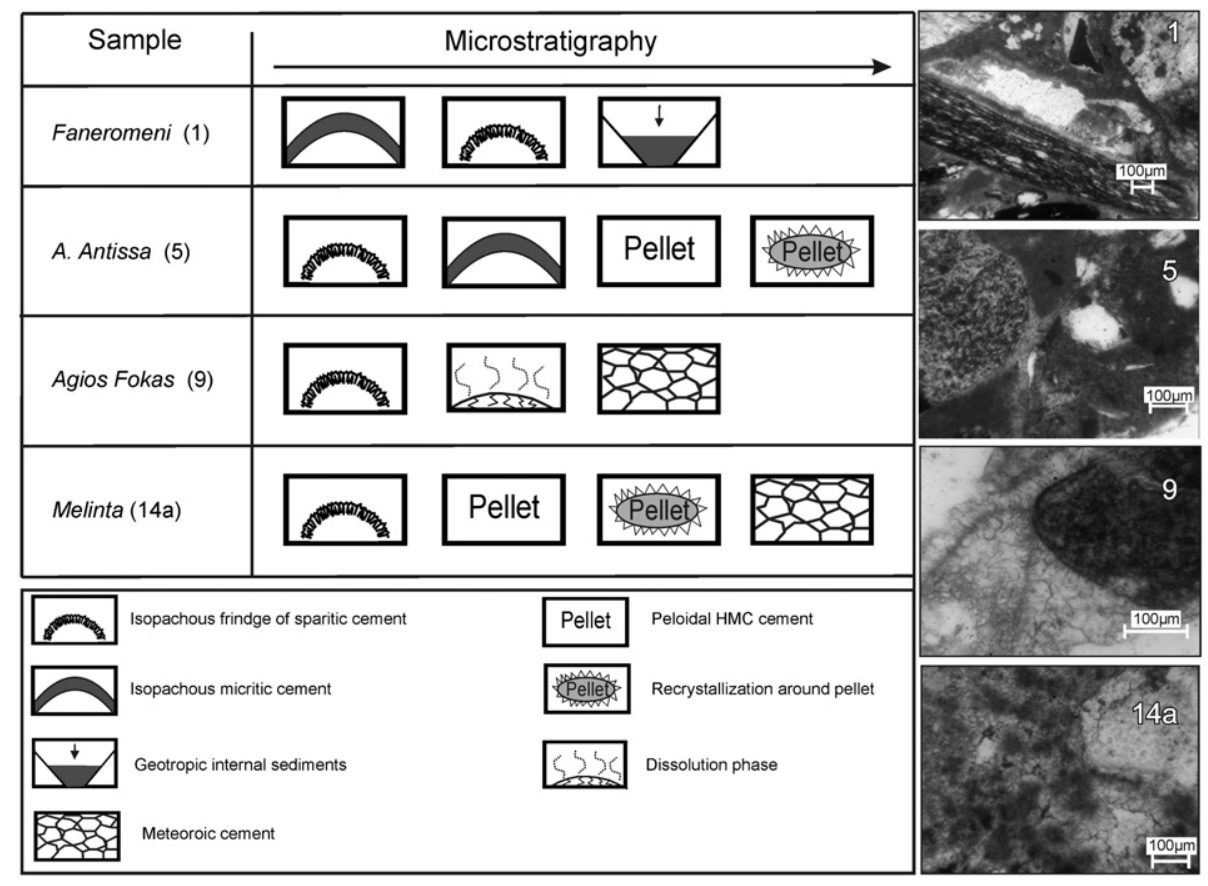

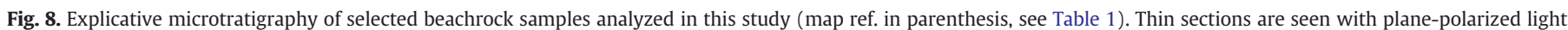

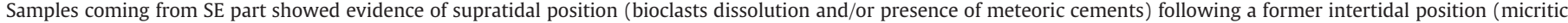

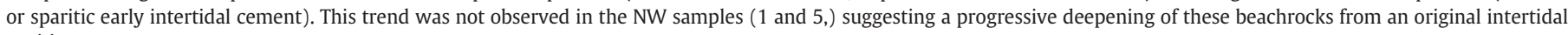
position.

\section{Discussion}

\subsection{Variability in paleo-shorelines elevation}

Elevation of paleo-shorelines mapped along the Lesvos coastline showed significant variability (Fig. 9a). Evidence of coastal uplift, clearly seen in the southeastern part of the island, is not present in the northwestern region where all the sea-level indicators are presently underwater. This indicates a different late Quaternary evolution of the two sectors, which is most likely due to local changes in tectonic regime (Stiros et al., 2000; Kontogianni et al., 2002; Cundy et al., 2010).

In fact, the complex tectonic environment of Lesvos makes the faulting regime extremely variable in strike and character (Fytikas et al., 1999; Zouros et al., 2008). According to the focal mechanism of shallow earthquakes in the area (Roumelioti et al., 2011), a large percentage of Lesvos faults show predominantly horizontal displacements, associated with strike slip regime (Pavlides et al., 2009). However, many northwest-southeast trending normal faults play an important role in shaping the coastal morphology of the southeastern part of Lesvos (Zouros et al., 2008; Pavlides et al., 2009). Moreover, the southeastern sector shows a different geomorphological setting with respect to the rest of the island characterized by steep cliffs and deeply-incised streams. These are normally considered typical features associated with fault activity and coastal uplift (Burbank and Anderson, 2001; Gaki-Papanastassiou et al., 2009; Cundy et al., 2010).

Raised shorelines in normal faulting terrains are often explained as the result of elastic or isostatic uplift of the footwall of normal active faults (Stiros et al., 2000; Palyvos et al., 2008). Despite the prevalence of studies related to on-land faulting, there are few offshore datasets showing active faults in the study area (Ocakoğlu et al., 2005). Among these, Mascle and Martin (1990) mapped east-west trending offshore normal faults such as the Lesvos Fault (LF, Fig. 9b), located less than $10 \mathrm{~km}$ off the southeast Lesvos coastline. Therefore, as indicated by bathymetry and topography (Mascle and Martin, 1990; Ocakoğlu et al., 2005), this area corresponds to the footwall of the Lesvos Fault (Fig. 9b), explaining the abundance of raised shorelines observed in this sector.

The absence of raised shorelines in northwest Lesvos seems to constrain the uplift trend to the southeastern part of the island. Furthermore, RSL stability of the NW sector is confirmed by the morphology of modern tidal notches. In fact, according to Pirazzoli (2007), the characteristics of notches in this sector (i.e., V-shaped form, maximum concavity near msl, base and the top of the notch corresponding respectively to the lowest and the highest tidal level) reflect a long period of sea-level stability. Additionally, absence of meteoric cements or dissolution phases in the microstratigraphy of beachrocks outcropping in the NW sector suggest their progressive deepening from the original intertidal position because of Holocene sea-level rise (Lambeck, 1996; Lambeck and Purcell, 2005); their average bathymetrical extent (from about -1 to $-1.8 \mathrm{~m}$ ) is in agreement with the last paleo-sea-level stand proposed by Desruelles et al. (2009) at $1000 \mathrm{cal}$ yr BP for tectonically stable areas of the Aegean. Thus, the high tectonic activity affecting this part of the island (mainly related to the right-lateral Aghia Paraskevi fault, Zouros et al., 2008; Roumelioti et al., 2011) may not produce local vertical movements as those identified along southeastern coastline.

\subsection{Evaluation of uplift trend}

According to the results of this study, the southeastern sector of the Lesvos coastline was characterized by a Late Quaternary coastal uplift, which was tectonically driven by the footwall of the Lesvos Fault. This raises the question whether the observed uplift is the result of a gradual and continuous uplift or the sum of different rapid (i.e. co-seismic) events. Several indicators seem to point to the latter as the most plausible. First, evidence is provided by the morphology of fossil tidal notches observed along the southeastern coastlines. According to several authors (Stiros, 1996; Pirazzoli et al., 1999; Rust and Kershaw, 2000; Pirazzoli, 2007), rapid changes in RSL, greater than the tidal range, suddenly uplift or submerge the whole notch, preserving it from further mid-littoral erosion. This setting was 
identified between the Panagia Krifti cove, the village of Melinda (Fig. 7a), as well as on the limestone blocks lying of the Agios Fokas platform (Fig. 5d). Secondly, evidence can be gathered from the biological remains observed upon the lower uplifted shore platform. Slow rates of uplift ( $\mathrm{mm}$ to $\mathrm{cm}$ per year) would have caused alteration and rapid destruction by mid-littoral erosion of this fragile fossil fauna. On the contrary, rapid co-seismic uplift strongly reduces the exposure of these species to the mid-littoral erosion allowing the preservation of fossil remains (Laborel and Laborel-Deguen, 1996; Stiros et al., 2000).

According to radiometric dating, the platform was uplifted between 3365 and $3963 \mathrm{cal}$ yr BP of $\sim 0.75 \pm 0.30 \mathrm{~m}$. Then, we processed this surface deformation value in order to get quantitative information on the seismogenic fault. Pavlides and Caputo (2004) proposed, for the Aegean region, the following relationship to estimate the expected magnitude given a paleoseismically observed displacement:

Ms $=0.59(\log M V D)+6.75 ;$

where Ms is the earthquake magnitude and MVD is the maximum vertical displacement.

Results indicated a magnitude (Ms) of 6.67 for the co-seismic event which uplifted the southeastern coast of Lesvos between 3365 and 3963 cal yr BP (Fig. 9b).

These data represent the first quantitative information on the offshore Lesvos Fault (LF) whose orientation and character are compatible
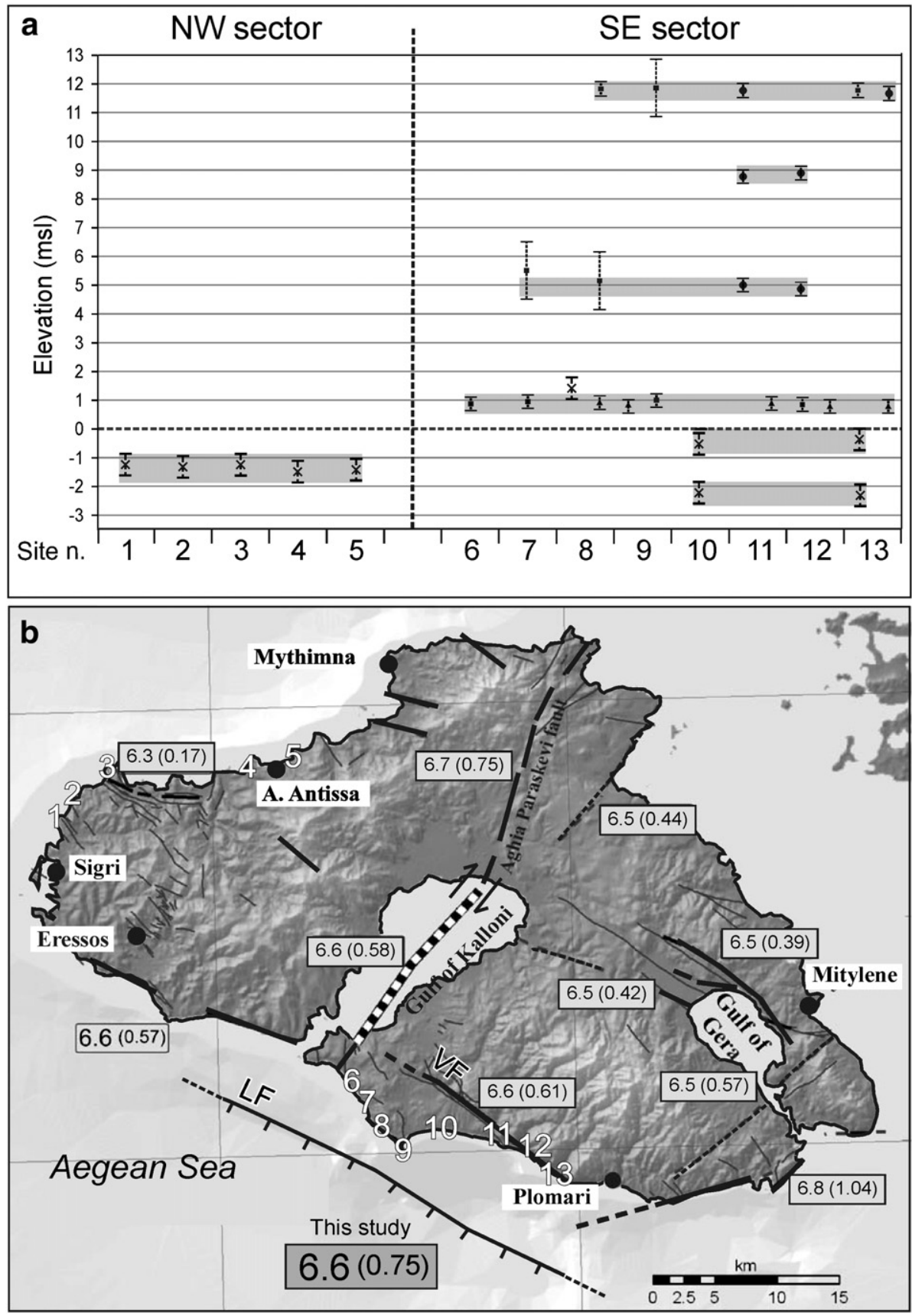

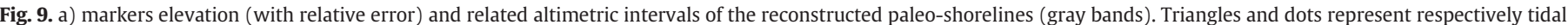

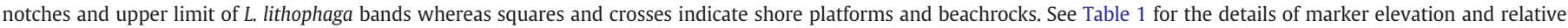

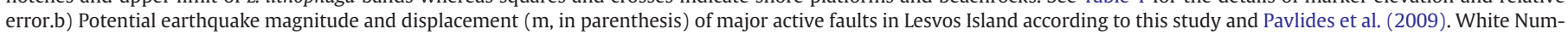
bers indicate the location of the paleo-sea-level markers reported in this study (see Table 1). VT is the Vatera Fault and LF is the Lesvos Fault. 
with the on-land Vatera Fault (VF) (Mascle and Martin, 1990; Ocakoğlu et al., 2005). For the latter, $0.6 \mathrm{~m}$ of vertical displacement associated with an expected Ms 6.6 earthquake was proposed on the basis of the seismotectonic characteristics and fault geometry (Fig. 9b, Pavlides et al., 2009) being in good agreement with the quantitative interpretation derived from our study. In addition, sea-level indicators recurred at about the same elevations along the southeastern sector (i.e. from the Gulf of Kalloni entrance to Plomari) and preliminary observations indicated evidence of coastal uplift as far as the entrance of the Gulf of Gera (Fig. 9b). Thus, the footwall of the Lesvos Fault could control an uplift trend recorded for about $50 \mathrm{~km}$ of coastline. This suggests the major importance of this fault in the tectonic setting of this sector of the Aegean.

Lack of dateable material and possible issues about the dating techniques does not permit the provision of precise chronological constraint for the higher paleo-shorelines. Indeed, radiocarbon dating of the paleo-sea-level stand reconstructed at approximately 5 and $11 \mathrm{~m}$ asl yielded upper Pleistocene ages $(\sim 29,000$ and $\sim 27,000$ cal yr BP, Table 2). Radiocarbon dating for such old samples could result in unreliable ages (Walker, 2005), therefore only a general pre-Holocene age can be attributed to the higher paleo-shorelines (Stiros et al., 2009). These higher shorelines can be tentatively attributed to interglacial isotopic stage 5 but correlation with other study sites is made difficult by the paucity of late Pleistocene RSL studies in the broad NE Aegean area. In addition, their present elevation must be the result of both variations in eustatic sea level and vertical movements associated to the Lesvos fault activity. This hypothesis cannot be confirmed without further chronological constraints which can be gathered only by applying different dating techniques. These new data are essential for assessing the vertical behavior of this coastal area, also providing the return intervals of co-seismic events and/or rates of long-term tectonic uplift.

\section{Conclusions}

The primary aim of this study was to assess the altimetric variability of paleo-shorelines on Lesvos, an area with a paucity of data related to RSL changes and coastal tectonics.

Two main conclusions can be gathered from the results of this study:

i) RSL changes at Lesvos were not homogenous and variations in the tectonic regime played a crucial role in coastal evolution. The NWSE trending faults on the southern shore of the island strongly control the coastal uplift observed between Plomari and the Gulf of Kalloni. On the contrary, northeastern sector tectonics, mainly related to the right-lateral Aghia Paraskevi fault (Fig. 9b, Zouros et al., 2008), did not produce vertical displacements. This is also confirmed by the RSL stability indicated by the morphology of modern notches observed in the Gavathas area;

ii) consideration concerning the paleoseismicity of the SE sector is now possible. Despite the lack of chronological data on the higher raised shorelines, the results provided evidence that the SE Lesvos was affected by events of co-seismic uplift during the Late Quaternary. The data presented here suggest that a Ms $=6.65$ earthquake took place between 3365 and 3963 cal yr BP, producing $0.75 \mathrm{~m}$ of vertical displacement. This confirms the potential seismic activity calculated in this sector of the island using fault geometry and seismic sources. Indicators of this co-seismic event recur from the entrance of the Kalloni Gulf to Plomari. Thus, activity of the offshore Lesvos Fault produced vertical displacements along more than $30 \mathrm{~km}$ of coastline. These data represent the first quantitative information on this fault and necessitate a reconsideration of its importance in the structural setting of this sector of the North Aegean basin. In addition, these results are a significant contribution to the knowledge of the offshore active faults of the
Aegean region, which is presently very limited because many epicenters are located offshore (Pavlides and Caputo, 2004).

In conclusion, we have provided the first field evidence of the coastal evolution of Lesvos, a region particularly representative of the neotectonics of the NE Aegean due to its location on the boundary between the North Aegean Trough and the West Anatolian Graben System. These results represent the basis for further investigation which should improve our data with new chronological constraints and new field data on other coastal tracts. These studies are essential both to corroborate our results and to provide information on the neotectonic behavior of this active sector of the Mediterranean.

\section{Acknowledgments}

MV wishes to thank Simon Engelhart (Sea-level Research, University of Pennsylvania) for his suggestions that greatly improved the earlier version of this paper as well as for the corrections of the English text. Authors kindly thank Giuseppe Mastronuzzi (Bari) and another anonymous reviewer who significantly improved the early version of the manuscript. Finally, we benefited greatly from the constructive comments and suggestions of the editor Prof. Andrew Plater.

\section{Appendix A. Supplementary data}

Supplementary data to this article can be found online at doi:10. 1016/j.geomorph.2012.03.004.

\section{References}

Antonioli, F., Ferranti, L., Lambeck, K., Kershaw, S., Verrubbi, V., Dai Pra, G., 2006. Late Pleistocene to Holocene record of changing uplift rates in southern Calabria and northeastern Sicily (southern Italy, Central Mediterranean Sea). Tectonophysics 422, 23-40.

Antonioli, F., Anzidei, M., Lambeck, K., Auriemma, R., Gaddi, D., Furlani, S., Orrù, P., Solinas, E., Gaspari, A., Karinja, S., Kovačić, V., Surace, L., 2007. Sea-level change during the Holocene in Sardinia and in the northeastern Adriatic (central Mediterranean Sea) from archaeological and geomorphological data. Quaternary Science Reviews 26, 2463-2486.

Burbank, D., Anderson, R., 2001. Tectonic Geomorphology. Blackwell Publishing, Oxford. 288 pp.

Collina-Girard, J., 2002. Underwater mapping of Late Quaternary submerged shorelines in the Western Mediterranean Sea and the Caribbean Sea. Quaternary International 192, 63-72.

Cundy, A.B., Gaki-Papanastassiou, K., Papanastassiou, D., Maroukian, H., Frogley, M.R., Cane, T., 2010. Geological and geomorphological evidence of recent coastal uplift along a major Hellenic normal fault system (the Kamena Vourla fault zone, NW Evoikos Gulf, Greece). Marine Geology 271, 156-164.

Desruelles, S., Fouache, É, Pavlopoulos, K., Dalongeville, R., Peulvast, J.-P., Coquinot, Y. Potdevin, J.-L., 2004. Beachrocks et variations récentes de la ligne de rivage en Mer Égée et dans l'ensemble insulaire Mykonos-Délos-Rhénée (Cyclades, Grèce) Géomorphologie: Relief, Processus, Environnement 1, 5-1.

Desruelles, S., Fouache, É., Ciner, A., Dalongeville, R., Pavlopoulos, K., Kosun, E. Coquinot, Y., Potdevin, J.L., 2009. Beachrocks and sea level changes since Middle Holocene: comparison between the insular group of Mykonos-Delos-Rhenia (Сyclades, Greece) and the southern coast of Turkey. Global and Planetary Change 66 (1-2), 19-33.

Erginal, A.E., Kiyak, N.G., Öztürk, B., 2010. Investigation of beachrock using microanalyses and OSL dating: a case study from Bozcaada Island, Turkey. Journal of Coastal Research 262, 50-358.

Evelpidou, N., Pavlopoulos, K., Vassilopoulos, A., Triantaphyllou, M., Vouvalidis, K., Syrides, G., 2011. Holocene palaeogeographical reconstruction of the western part of Naxos island (Greece). Quaternary International. doi:10.1016/j.quaint.2011.08.002.

Evelpidou, N., Vassilopoulos, A., Pirazzoli, P.A., 2012. Submerged notches on the coast of Skyros Island (Greece) as evidence for Holocene subsidence. Geomorphology 141-142, 81-87.

Ferranti, L., Antonioli, F., Mauz, B., Amorosi, A., Dai Pra, G., Mastronuzzi, G., Monaco, C., Orrù, P., Pappalardo, M., Radtke, U., Renda, P., Romano, P., Sansò, P., Verrubbi, V., 2006. Markers of the last interglacial sea-level high stand along the coast of Italy: tectonic implications. Quaternary International 145-146, 30-54.

Ferranti, L., Monaco, C., Antonioli, F., Maschio, L., Kershaw, S., Verrubbi, V., 2007. The contribution of regional uplift and coseismic slip to the vertical crustal motion in the Messina Straits, southern Italy: evidence from raised Late Holocene shorelines. Journal of Geophysical Research 112, B06401. doi:10.1029/2006JB004473.

Ferranti, L., Monaco, C., Morelli, D., Antonioli, F., Maschio, L., 2008. Holocene activity of the Scilla Fault, Southern Calabria: insights from coastal morphological and structural investigations. Tectonophysics 453, 74-93. 
Filocamo, F., Romano, P., Di Donato, V., Esposito, P., Mattei, M., Porreca, M. Robustelli, G., Russo Ermolli, E., 2009. Geomorphology and tectonics of uplifted coasts: new chronostratigraphical constraints for the Quaternary evolution of Tyrrhenian North Calabria (southern Italy). Geomorphology 105 (3-4) 334-354

Fouache, É., Desruelles, S., Pavlopoulos, K., Dalongeville, R., Coquinot, Y., Peulvast, J.-P., Potdevin, J.-L., 2005. Using beachrocks as sea level indicators in the insular group of Mykonos, Delos and Rhenia (Cyclades, Greece). Zeitschrift für Geomorphologie 137, 37-43.

Fytikas, M., Lombardi, S., Papachristou, M., Pavlides, S., Zouros, N., Soulakellis, N., 1999 Investigation of the 1867 Lesbos (NE Aegean) earthquake fault pattern based on geochemical data. Tectonophysics 308, 249-261.

Gaki-Papanastassiou, K., Karymbalis, E., Papanastassiou, D., 2009. Quaternary marine terraces as indicators of neotectonic activity of the Ierapetra normal fault SE Crete (Greece). Geomorphology 104, 38-46.

Ghilardi, M., Fouache, Queyrel, F., Syrides, G., Vouvalidis, K., Kunesch, S., Styllas, M. Stiros, S., 2008a. Human occupation and geomorphological evolution of the Thessaloniki Plain (Greece) since Mid-Holocene. Journal of Archaeological Science 35 (1), 111-125.

Ghilardi, M., Kunesch, S., Styllas, M., Fouache, 2008b. Recontruction of Mid-Holocene sedimentary environments in the central part of the Thessaloniki Plain (Greece) based on microfaunal identification, magnetic susceptibility, and grain-size analysis. Geomorphology 97, 617-630.

Kellettat, D., 2006. Beachrock as sea-level indicator? Remarks from a geomorphological point of view. Journal of Coastal Research 22, 1558-1564.

Kershaw, S., Guo, L., 2001. Marine notches in coastal cliffs: indicators of relative sea level change, Perachora Peninsula, central Greece. Marine Geology 179, 213-228.

Kiratzi, A., Louvari, E., 2003. Focal mechanisms of shallow earthquakes in the Aegean Sea and the surrounding lands determined by waveform modelling: a new database. Journal of Geodynamics 36 (1-2), 251-274.

Knight, J., 2007. Beachrock reconsidered. Discussion of: Kellettat, D. 2006. Beachrock as sea-level indicator? Remarks from a geomorphological point of view. Journal of Coastal Research, 22, 1558-1564. Journal of Coastal Research 23 (4), 1074-1078.

Kontogianni, V.A., Tsoulos, N., Stiros, S., 2002. Coastal uplift, earthquakes and active faulting of Rhodes Island (Aegean Arc): modeling based on geodetic inversion. Marine Geology 186, 299-317.

Koral, H., Öztürk, H., Hanilçi, N., 2009. Tectonically induced coastal uplift mechanism of Gökçeada Island, Northern Aegean Sea, Turkey. Quaternary International 197 43-54.

Koufos, G.D., Zouros, N., Mourouzidou, O., 2003. Prodeinotherium bavaricum (Proboscidea, Mammalia) from Lesvos island, Greece; the appearance of deinotheres in the eastern Mediterranean. Geobios 36, 305-315.

Kouly, M. Seymour, K.S. 2006. Contribution of remote sensing techniques to the identification and characterization of Miocene calderas, Lesvos Island, Aegean Sea Hellas. Geomorphology 77, 1-16

Laborel, J., Laborel-Deguen, F., 1996. Biological indicators of Holocene sea-level and climatic variations on rocky coasts of tropical and subtropical regions. Quaternary International 31, 53-60.

Lambeck, K., 1996. Sea-level changes and shore-line evolution in Aegean Greece since Upper Paleolithic time. Antiquity 70, 588-610.

Lambeck, K., Purcell, A., 2005. Sea-level change in the Mediterranean Sea since the LGM: model predictions for tectonically stable areas. Quaternary Science Reviews 24, 1969-1988.

Lambeck, K., Antonioli, F., Purcell, A., Silenzi, S., 2004. Sea-level change along the Italian coast for the past 10,000 yr. Quaternary Science Reviews 23 (14-15), 1567-1598.

Longman, M.W., 1980. Carbonate diagenetic textures from nearsurface diagenetic environments. AAPG Bulletin 64, 461-487.

Mascle, J., Martin, L., 1990. Shallow structure and recent evolution of the Aegean Sea: synthesis based on continuous reflection profiles. Marine Geology 94, 271-299.

Mastronuzzi, G., Sansò, P., 2002. Holocene uplift rates and historical rapid sea-level changes at the Gargano promontory, Italy. Journal of Quaternary Science 17 (5-6), 593-606

Mountrakis, D., Thomaidou, E., Zouros, N., Kilias, A., 2001. Kinematic analysis and tertiary evolution of the Lesvos ophiolites and metamorphic sole (Aegean sea, Greece). Bulletin of the Geological Society of Greece XXXIV/1, 267-274.

Neumeier, U., 1998. Le rôle de l'activité microbienne dans la cimentation précoce des beachrocks (sédiments intertidaux). PhD Thesis 2994, University of Geneva. 183 pp.

Neumeier, U., 1999. Experimental modelling of beachrock cementation under microbial influence. Sedimentary Geology 126 (1-4), 35-46.

Neumeier, U., Bernier, P., Dalongeville, R., Obertin, C., 2000. Holocene sea-level changes underlined by beachrock features and diagenesis: example from Damnoni (Crete). Géomorphologie: Relief, Processus, Environnement 4, 211-220.

Nixon, F.C., Reinhardt, E.G., Rothaus, R., 2009. Foraminifera and tidal notches: dating neotectonic events at Korphos, Greece. Marine Geology 257, 41-53.

Novak, I.D., Soulakellis, N., 2000. Identifying geomorphic features using LANDSAT-5/TM data processing techniques on Lesvos, Greece. Geomorphology 34, 101-109.

Ocakoğlu, N., Demirbağ, E., Kuşçu, I., 2005. Neotectonic structures in Izmir Gulf and surrounding regions (western Turkey): Evidences of strike-slip faulting with compression in the Aegean extensional regime. Marine Geology 219, 155-171.

Palyvos, N., Lemeille, F., Sorel, D., Pantosti, D., Pavlopoulos, K., 2008. Geomorphic and biological indicators of paleoseismicity and Holocene uplift rate at a coastal norma fault footwall (western Corinth Gulf, Greece). Geomorphology 96, 16-38.

Papazachos, C.B., Kiratzi, A.A., 1996. A detailed study of the active crustal deformation in the Aegean and surrounding area. Tectonophysics 253 (1-2), 129-153.

Papazachos, B., Papazachou, K., 1997. Earthquakes of Greece, Ziti Editions, Thessaloniki, Greece. 304 pp.
Papazachos, B.C., Papadimitriou, E.E., Kiratzi, A.A., Papazachos, C.B., Louvari, E.K., 1998. Fault plane solutions in the Aegean sea and the surrounding area and their tectonic implications. Bollettino di Geofisica Teorica ed Applicata 39, 199-218.

Pavlides, S., Caputo, R., 2004. Magnitude versus faults' surface parameters: quantitative relationships from the Aegean Region. Tectonophysics 380 (3-4), 159-188.

Pavlides, S., Tsapanos, T., Zouros, N., Sboras, S., Koravos, G., Chatzipetros, A., 2009. Using active fault data for assessing seismic hazard: a case study from NE Aegean sea, Greece. Earthquake Geotechnical Engineering Satellite Conference XVIIth International Conference on Soil Mechanics \& Geotechnical Engineering 2-3. 10. 2009, Alexandria, Egypt.

Pavlopoulos, K., Triantaphyllou, M., Karymbalis, E., Karkanas, P., Kouli, K., Tsourou, T., 2007. Landscape evolution recorded in the embayment of Palamari (Skyros Island, Greece) from the begining of the Bronze Age until recent times. Geomorphologie 1, 37-48.

Pavlopoulos, K., Triantaphyllou, M., Karkanas, P., Kouli, K., Syrides, G., Vouvalidis, K. Palyvos, N., Tsourou, T., 2010. Paleoenvironmental evolution and prehistoric human environment in the embayment of Palamari (Skyros island, Greece) during middle-late Holocene. Quaternary International 216, 41-53.

Pe-Piper, G., Piper, D.J.W., 1992. Geochemical variation with time in the Cenozoic high$\mathrm{k}$ volcanic rocks of the island of Lesbos, Greece: significance for shoshonite petrogenesis. Journal of Volcanology and Geothermal Research 53 (1-4), 371-387.

Perissoratis, C., Cosnipoliatis, N., 2003. The impacts of sea-level changes during latest Pleistocene and Holocene times on the morphology of the Ionian and Aegean seas (SE Alpine Europe). Marine Geology 196, 145-156.

Pirazzoli, P.A., 2005. A review of possible eustatic, isostatic and tectonic contributions in eight late-Holocene relative sea-level histories from the Mediterranean area. Quaternary Science Review 24, 1989-2001.

Pirazzoli, P.A., 2007. Sea level studies. Geomorphological indicators. Encyclopedia of Quaternary Science 2974-2983.

Pirazzoli, P.A., Stiros, S.C., Arnold, M., Laborel, J., Laborel-Deguen, F., 1999. Late Holocene coseimic vertical displacements and tsunami deposits near Kynos, Gulf of Euboea, central Greece. Physics and Chemistry of the Earth, Part A, Solid Earth and Geodesy 24, 361-367.

Pirazzoli, P.A., Stiros, S.C., Fontugne, M., Arnold, M., 2004. Holocene and Quaternary uplift in the central part of the southern coast of the Corinth Gulf (Greece). Marine Geology 212, 35-44.

Poulos, S.E., Ghionis, G., Maroukian, H., 2009. Sea-level rise trends in the AtticoCycladic region (Aegean Sea) during the last 5000 years. Geomorphology 107, $10-17$.

Reimer, P.J., Baillie, M.G.L., Bard, E., Bayliss, A., Beck, J.W., Blackwell, P.G., Bronk Ramsey, C., Buck, C.E., Burr, G.S., Edwards, R.L., Friedrich, M., Grootes, P.M., Guilderson, T.P., Hajdas, I., Heaton, T.J., Hogg, A.G., Hughen, K.A., Kaiser, K.F., Kromer, B., McCormac, F.G., Manning, S.W., Reimer, R.W., Richards, D.A., Southon, J.R., Talamo, S., Turney, C.S.M., van der Plicht, J., Weyhenmeyer, C.E., 2009. Calibration datasets. Radiocarbon $51,1111-1150$

Riedl, R., 1964. Die Erscheinungen der Wasserbewegung und ihre Wirkung auf Sedentarier im Mediterranen Felslitoral. Helgoland Marine Research 10, 155-186.

Roumelioti, Z., Kiratzi, A., Benetatos, C., 2011. Time domain moment tensors of earthquakes in the broader Aegean Sea for the years 2006-2007: the database of the Aristotle University of Thessaloniki. Journal of Geodynamics 51, 179-189.

Rovere, A., Parravicini, V., Vacchi, M., Montefalcone, M., Morri, C., Bianchi, C.N., Firpo, M., 2010. Geo-environmental cartography of the Marine Protected Area "Isola di Bergeggi"(Liguria, NW Mediterranean Sea). Journal of Maps 505-519. doi:10.4113/ jom.2010.1137.

Rovere, A., Vacchi, M., Firpo, M., Carobene, L., 2011a. Underwater geomorphology of the coastal tracts between Finale ligure and Vado ligure. Quaternary International 232 (1-2), 187-200.

Rovere, A., Vacchi, M., Parravicini, V., Bianchi, C.N., Zouros, N., Firpo, M., 2011b. Bringing geoheritage underwater: definitions, methods, and application in two Mediterranean marine areas. Environmental Earth Sciences 64, 133-142.

Rust, D., Kershaw, S., 2000. Holocene tectonic uplift patterns in northeastern Sicily: evidence from marine notches in coastal outcrops. Marine Geology 167, 105-126.

Schembri, P.J., Deidun, A., Mallia, A., Marcieca, L., 2005. Rocky shore biotic assemblages of the Maltese Islands (Central Mediterranean): a conservation perspective. Journal of Coastal Research 21 (1), 157-166.

Scicchitano, G., Spampinato, C.R., Ferranti, L., Antonioli, F., Monaco, C., Capano, M., Lubritto, C., 2011. Uplifted Holocene shorelines at Capo Milazzo (NE Sicily, Italy): evidence of co-seismic and steady-state deformation. Quaternary International 232 (1-2), 201-213.

Siani, G., Paterne, M., Arnold, M., Bard, E., Metivier, B., Tisnerat, N., Bassinot, F., 2000. Radiocarbon reservoir ages in the Mediterranean Sea and Black Sea. Radiocarbon 42 (2), 271-280.

Stewart, I.S., Morhange, C., 2009. Coastal geomorphology and sea-level change. In: Woodward, J.C. (Ed.), The Physical Geography of the Mediterranean. Oxford University Press, Oxford, pp. 385-413.

Stiros, S., 1996. Late Holocene relative sea level changes in SW Crete: evidence of an unusual earthquake cycle. Annali di Geofisica 39, 677-687.

Stiros, S.C., Laborel, J., Laborel-Deguen, F., Papageorgiou, S., Evind, J., Pirazzoli, P.A., 2000. Seismic coastal uplift in a region of subsidence: Holocene raised shorelines of Samos Island, Aegean Sea, Greece. Marine Geology 170, 41-58.

Stiros, S.C., Pirazzoli, P.A., Fontugne, M., 2009. New evidence of Holocene coastal uplift in the Strophades Islets (W Hellenic Arc, Greece). Marine Geology 267, 207-211.

Stuiver, M., Reimer, P.J., 1993. Extended ${ }^{14} \mathrm{C}$ database and revised CALIB radiocarbon calibration program. Radiocarbon 35, 215-230.

Turner, R.J., 2005. Beachrocks. In: Schwartz, M.L. (Ed.), Encyclopedia of Coastal Science, pp. 24-25. Dordrecht. 
Velegrakis, A.F., Vousdoukas, M.I., Andreadis, A., Adamakis, G., Pasakalidou, E., Meligonitis, R., Kokolatos, G., 2008. Influence of dams on downstream beaches: Eressos, Lesbos, Eastern Mediterranean. Marine Georesources and Geotechnology 26, 350-371.

Vött, A., Bareth, G., Brückner, H., Curdt, C., Fountoulis, I., Grapmayer, R., Hadler, H., Hoffmeister, D., Klasen, N., Lang, F., Masberg, P., May, S.M., Ntageretzis, K., Sakellariou, D., Willershäuser, T., 2010. Beachrock-type calcarenitic tsunamites along the shores of the eastern Ionian Sea (western Greece) case studies from Akarnania, the Ionian Islands and the western Peloponnese. Zeitschrift für Geomorphologie 54 (3), 1-50.

Vousdoukas, M.I., Velegrakis, A.F., Plomaritis, T.A., 2007. Beachrock occurrence, characteristics, formation mechanisms and impacts. Earth Science Review 85, 23-46.

Vousdoukas, M.I., Velegrakis, A.F., Dimou, K., Zervakis, V., Conley, D.C., 2009a. Wave run-up observations in microtidal, sediment-starved pocket beaches of the Eastern Mediterranean. Journal of Marine Systems 78, 37-47.
Vousdoukas, M.I., Velegrakis, A.F., Karambas, T.V., 2009b. Morphology and sedimentology of a microtidal beach with beachrocks: Vatera, Lesbos, NE Mediterranean. Continental Shelf Research 29, 1937-1947.

Walker, M.J.C., 2005. Quaternary Dating Methods. Wiley, England. 286 pp.

Zouros, N., 2007. Geomorphosite assessment and management in protected areas of Greece. The case of the Lesvos island coastal geomorphosites. Geographica Helvetica 62, 169-180.

Zouros, N., Pavlides, S., Kiratzi, A.A., Kakakaisis, G., Drakatos, G., Soulakellis, N., Vaitis, M. Tsapanos, T., Chatzipetros, A., Ganas A., Sboras, S., Koravos G., Koukourouvli, N., Lampaki, O., Valiakos, I., 2008. Active fault and seismicity maps of the North Aegean region (6 maps, 1:200.000, 1:100.000). Research project final report: Use of modern research tools in geosciences for seismic hazard management in NE Aegean islands, Natural History Museum of the Lesvos Petrified Forest, Mytilene, Lesvos, Greece. http://naseismic.geo.aegean.gr. 